This PDF is a selection from an out-of-print volume from the National Bureau of Economic Research

Volume Title: Cost of Providing Consumer Credit: A Study of Four Major Types of Financial Institutions

Volume Author/Editor: Paul F. Smith

Volume Publisher: NBER

Volume ISBN: 0-87014-397-2

Volume URL: http://www.nber.org/books/smit62-1

Publication Date: 1962

Chapter Title: Cost of Providing Consumer Credit: A Study of Four Major Types of Financial Institutions

Chapter Author: Paul Smith

Chapter URL: http://www.nber.org/chapters/c1783

Chapter pages in book: (p. 1 - 21) 


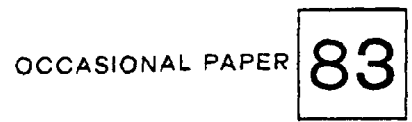

\section{COST OF PROVIDING CONSUMER CREDIT}

A Study of Four Major Types of Financial Institutions

PAUL SMITH

NATIONAL BUREAU OF 
Reprinted from the September 1962 issue of

The Journal of Finance

Library of Congress Catalog Card Number 62-21871

Price: $\$ 0.50$

National Bureau of Economic Research, Inc.

261 Madison Avenue, New York 16, N. Y. 


\section{NATIONAL BUREAU OF ECONOMIC RESEARCH}

1962

Harold M. Groves, Chairman

OFFICERS

Arthur F. Burns, President

Albert J. Hettinger, Jr., Vice President

Donald B. Woodward, Treasurer

Solomon Fabricant, Director of Research

Geoffrey H. Moore, Associate Director of Research

Hal B. Lary, Associate Director of Research

William J. Carson, Executive Director

Robert B. Anderson, New York City

DIRECTORS AT LARGE

Wallace J. Campbell, Nationwide Insurance

Erwin D. Canham, Christian Science Monitor

Solomon Fabricant, New York University

Marion B. Folsom, Eastman Kodak Company

Crawford H. Greenewalt, E. I. du Pont de Nemours d Company

Gabriel Hauge, Manufacturers Hanover Trust Company

A. J. Hayes, International Association of Machinists

Albert J. Hettinger, Jr., Lazard Frères and Company

Nicholas Kelley, Kelley Drye Newhall Maginnes \& Warren

H. W. Laidler, League for Industrial Democracy

George B. Roberts, Larchmont, New York

Harry Scherman, Book-of-the-Month Club

Boris Shishkin, American Federation of Labor and Congress of Industrial Organizations

George Soule, South Kent Connecticut

Joseph H. Willits, Armonk, New York

Donald B. Woodward, A. W. Jones and Company

Theodore O. Yntema, Ford. Motor Company

V. W. Bladen, Toronto

Arthur F. Burns, Columbia

Lester V. Chandler, Princeton

Melvin G. de Chazeau, Cornell

Frank W. Fetter, Northwestern

R. A. Gordon, California

Harold M. Groves, Wisconsin

Gottfried Haberler, Harvard.
DIRECTORS BY UNIVERSITY APPOINTMENT

Walter W. Heller, Minnesota

Maurice W. Lee, North Carolina

Lloyd G. Reynolds, Yale

Paul A. Samuelson, Massachusetts

Institute of Technology

Theodore W. Schultz, Chicago

Willis J. Winn, Pennsylvania

DIRECTORS BY APPOINTMENT OF OTHER ORGANIZATIONS

Percival F. Brundage, American Institute of Certified Public Accountants

Harold G. Halcrow, American Farm Economic Association

Theodore V. Houser, Committee for Economic Development

S. H. Ruttenberg, American Federation of Labor and Congress of Industrial Organizations

Murray Shields, American Management Association

Willard L. Thorp, American Economic Association

W. Allen Wallis, American Statistical Association

Harold F. Williamson, Economic History Association

Shepard Morgan, Norfolk, Connecticut

DIRECTORS EMERITI

N. I. Stone, New York City 


\section{RELATION OF THE DIRECTORS TO THE WORK AND PUBLICATIONS OF THE NATIONAL BUREAU OF ECONOMIC RESEARCH}

1. The object of the National Bureau of Economic Research is to ascertain and to present to the public important economic facts and their interpretation in a scientific and impartial manner. The Board of Directors is charged with the responsibility of ensuring that the work of the National Bureau is carried on in strict conformity with this object.

2. To this end the Board of Directors shall appoint one or more Directors of Research.

3. The Director or Directors of Research shall submit to the members of the Board, or to its Executive Committee, for their formal adoption, all specific proposals conceming researches to be instituted.

4. No report shall be published until the Director or Directors of Research shall have submitted to the Board a summary drawing attention to the character of the data and their utilization in the report, the nature and treatment of the problems involved, the main conclusions, and such other information as in their opinion would serve to determine the suitability of the report for publication in accordance with the principles of the National Bureau.

5. A copy of any manuscript proposed for publication shall also be submitted to each member of the Board. For each manuscript to be so submitted a special committee shall be appointed by the President, or at his designation by the Executive Director, consisting of three Directors selected as nearly as may be one from each general division of the Board. The names of the special manuscript committee shall be stated to each Director when the summary and report described in paragraph (4) are sent to him. It shall be the duty of each member of the committee to read the manuscript. If each member of the special committee signifies his approval within thirty days, the manuscript may be published. If each member of the special committee has not signified his approval within thirty days of the transmittal of the report and manuscript, the Director of Research shall then notify each member of the Board, requesting approval or disapproval of publication, and thirty additional days shall be granted for this purpose. The manuscript shall then not be published unless at least a majority of the entire Board and a two-thirds majority of those members of the Board who shall have voted on the proposal within the time fixed for the receipt of votes on the publication proposed shall have approved.

6. No manuscript may be published, though approved by each member of the special conmittee, until forty-five days have elapsed from the transmittal of the summary and report. The interval is allowed for the receipt of any memorandum of dissent or reservation, together with a brief statement of his reasons, that any member may wish to express; and such memorandum of dissent or reservation shall be published with the manuscript if he so desires. Publication does not, however, imply that each member of the Board has read the manuscript, or that either members of the Board in general, or of the special committee, have passed upon its validity in every detail.

7. A copy of this resolution shall, unless otherwise determined by the Board, be printed in each copy of every National Bureau book.

(Resolution adopted October 25, 1926, as revised February 6, 1933, and February 24, 1941) 


\section{FOREWORD}

This is the first report of research findings to emerge from a broad study of consumer credit that ains to assess its role in the functioning of the United States economy. The various segments of the National Bureau's study focus upon analysis of consumer credit markets and upon the impact of credit on consumer behavior. A major objective is to provide answers to questions frequently asked concerning finance rates paid by consumers and the corresponding costs incurred by financial institutions which hold the credit contracts.

Paul Smith's study explores the interrelations between rates of charge and major cost components of four important types of financial institutions which extend a wide range of consumer credit in varying forms. The report presents comparative cost data for the year 1959, the most recent year of the ten-year period covered by his investigation. The final monograph will cover the trends revealed during the period and their relation to the earlier National Bureau study by Ernst A. Dauer, Comparative Operating Experience of Consumer Instalment Financing Agencies and Commercial Banks, $1929-41$ (1944).

The institutions represented in this report, with the exception of the credit unions (for which comprehensive data are published), are large firms. The nine consumer finance companies in the sample held 55 per cent of the total consumer finance company loans estimated by the Federal Reserve Board to be held in mid-1955; the ten sales finance companies represented 67 per cent of their group's holdings in the same Federal Reserve survey estimates; and the nine commercial banks held almost 7 per cent of the consumer instalment credit outstanding at all commercial banks at year-end 1959. While the data cannot be considered as representative of all segments of the institutions which extend credit to consumers, they are certainly typical of many large suppliers of credit 
within the finance company and bank groups, and they do cover all federal credit unions.

Other projects in the consumer credit study are closely related to this report. An analysis of the rate structure in automobile finance by Robert P. Shay will provide detailed estimates of the cost to consumers of financing the purchase of new and used automobiles. Wallace P. Mors is investigating economic aspects of the regulatory policies of states toward consumer credit. The effects of credit use upon the management of consumer finances are being studied by $\mathrm{F}$. Thomas Juster. Richard $\mathrm{T}$. Selden is conducting an investigation of the flow of funds from their sources through financial markets to their ultimate use by consumers. Finally, the impact of consumer indebtedness upon unemployed families is being appraised by Philip A. Klein. A summary volume combining research results is planned.

Robert P. Shay 


\title{
COST OF PROVIDING CONSUMER CREDIT: A STUDY OF FOUR MAJOR TYPES OF FINANCIAL INSTITUTIONS*
}

\author{
Paul Smith $\dagger$
}

INSTITUTIONS LENDING TO CONSUMERS range from small retail establishments to billion-dollar financial organizations. They vary in size, structure, type of business conducted, operating techniques, quality of management, and competitive strength. Their credit contracts

* Prepared for presentation at the annual meetings of the American Finance Association, December 28, 1961, this paper is part of a broad consumer finance research project at the National Bureau of Economic Research under the general direction of Robert $\mathbf{P}$. Shay. The other aspects of consumer credit covered in the project include finance rates, state legislation, sources of funds, and the consumer use of credit.

I am particularly indebted to John M. Chapman, of Columbia University, and to Geoffrey H. Moore and Robert P. Shay, of the National Bureau, for their help and counsel. Other members of the National Bureau staff who reviewed earlier drafts and made thoughtful suggestions are Reuben Kessel, Anna J. Schwartz, and F. Thomas Juster. Robert W. Johnson, of Michigan State University, contributed belpful comments.

Members of the Advisory Committee of the Consumer Credit Study who assisted in the planning and revision of earlier drafts of this report are Paul W. McCracken (chairman), Dorothy S. Brady, John M. Chapman, George Dimmler, Mona Dingle, Bertrand Fox, Raymond W. Goldsmith, Robert E. Lewis, Roger F. Murray, George W. Omacht, Roland I. Robinson, Sidney E. Rolfe, Herbert Stein, Van Buren Thorne, Jr., Leroy A. Weller, and William L. Wilson.

Special acknowledgment is due the financial institutions which contributed data to the study. Particular mention should be made of the help given by William $\mathrm{S}$. Germer and H. F. Wright, Jr., of the First Pennsylvania Bank and Trust Company; Ernst A. Dauer, of Housebold Finance Corporation; M. R. Neifeld and Charles A. Loeffler, of Beneficial Management Corporation; R. F. Murphy, of General Motors Acceptance Corporation; and George F. Dimmler, of C.I.T. Financial Corporation. Roland M. Gardner and other staff members of the Bureau of Federal Credit Unions advised on the use of the credit-union data.

Statistical and accounting assistance was capably given by Florence Liang, of the National Bureau, and V. N. Vora, of the University of Pennsylvania. Christine Culbert, of the National Bureau editorial staff, provided editorial assistance.

This report is part of a broad study of consumer credit being conducted by the National Bureau of Economic Research, made possible by research grants from four finance companies: Associates Investment Company, C.I.T. Financial Corporation, General Motors Acceptance Corporation, and Pacific Finance Corporation. In addition, the author is indebted to the Wharton School of Finance and Commerce of the University of Pennsylvania for permission to use part of the time and facilities made available through a chair in consumer credit given to the University by the Family Finance Corporation. These institutions are, of course, not to be held responsible for any of the statements made or views expressed herein.

† Associate professor of finance, Wharton School of Finance and Commerce, University of Pennsylvania. 
offer an almost endless variety in size, terms, risk, and service. Their charges reflect these differences and the variations in costs that they entail.

This paper presents some of the data collected by the National Bureau of Economic Research that were designed to ascertain the costs of different types of consumer credit obligations, in order to understand the level and structure of the finance rates paid by consumers. As it was not feasible to develop over-all cost estimates by type of obligation, the subsequent analysis is devoted largely to cost differences among institutions which include differences attributable to variations in the types of credit provided.

Information was obtained from small samples of commercial banks, consumer finance companies, and sales finance companies. The size and composition of the samples were determined by the willingness and ability of the companies to report the details required. The results do not necessarily represent all segments of the consumer credit industry. Similar material was also prepared for all federal credit unions from published information. Reports in preparation will relate the data on costs presented here to the level and variations in the finance rates paid by consumers.

The finance company samples were composed of nine large consumer finance companies and ten large sales finance companies. The distinction between consumer finance and sales finance companies was based on the concentration of their consumer receivables. The consumer finance companies operated primarily under state smallloan laws and held an average of 90 per cent of their receivables in personal loans. However, most of the sample companies also held small amounts of sales finance paper. The sales finance companies engaged primarily in purchasing new and used automobile paper and held an average of 73 per cent of their consumer receivables in such paper. They also purchased other types of retail paper and held substantial amounts of personal loans. Both samples accounted for more than half the outstanding receivables in their respective industries. At the end of 1959 , all sales finance companies held $\$ 10.1$ billion of consumer credit and consumer finance companies held $\$ 3.8$ billion.

The commercial bank sample consisted of nine banks of varying sizes and from different parts of the country. Although all the banks in the sample had sizable consumer credit operations, together they held only 7 per cent of the $\$ 18.8$ billion in consumer credit held by all commercial banks at the end of 1959. Most of the sample banks engaged in all major types of consumer financing. They purchased 
indirect automobile paper and other contracts from dealers and made direct personal loans of many types.

Many adjustments had to be made in data from different institutions to force them into a common accounting mold. These adjustments and estimates were far too numerous to discuss here. Some were straightforward and would commonly be regarded as appropriate. Others were problematical and involved conceptual decisions. A detailed description of the methods used will be presented with the final results of the study.

\section{Range and Composition of Finance Charges}

The variation in gross finance charges on consumer credit is impressive. ${ }^{1}$ Average annual charges per $\$ 100$ of credit outstanding in 1959 varied from $\$ 9$ to $\$ 24$ at the four types of institutions studied (Table 1). Averages for individual companies showed a range from $\$ 7$ to $\$ 30$ per $\$ 100$. These differences reflect many variations in amount and type of credit extended, as well as alternative cost factors faced by different institutions.

A substantial part of the differences in finance charges can be traced to the handling and operating costs of the type of lending performed by the institutions. The lender's decisions on the maturity, size, and type of loan to be made and the character of the credit risk he assumes determine the general level of his costs. His individual operating procedures and efficiency establish his own particular pattern of costs.

Other differences in charges stem from the legal, tax, and institutional framework within which the lender operates. These differences are of special interest because they determine the ability of lenders to compete in similar markets and because they have implications about the economic effects of legislative action. Perhaps the sharpest difference among the institutions studied occurs between the federal credit unions and the other three types. Credit unions are owned by the users (borrowers and savers) while ownership of the commercial banks, consumer finance companies, and sales finance companies rests in stockholders.

Table 1 gives a breakdown of the expenses of providing credit at each type of institution and indicates the importance of each cost component in the gross finance charge. Annual operating expenses, which include all the day-to-day costs of handling accounts, ranged from $\$ 3.30$ per $\$ 100$ of credit outstanding to nearly five times that

1. See note + to Table 1. 
amount, or $\$ 14.25$ per $\$ 100$. The cost of money varied from $\$ 3.92$ to - $\$ 6.89$ per $\$ 100$, and the costs of income taxes varied from zero to $\$ 2.73$ per $\$ 100$.

The distribution of costs also varied widely. Operating expenses and payments to dealers accounted for from 48 to 64 per cent of total costs at the three types of stockholder-owned institutions. The cost of non-equity funds, provisions for income taxes, and profit made up the remainder. With the exception of credit unions, the cost of funds (interest and profit) was not the major element in total cost to the

TABLE $1^{*}$

\section{COMPONENTS OF Gross Finance Charges on CONSUMER \\ CREDIT BY TYPE OF LENDER, 1959}

(Dollars per $\$ 100$ of Average Outstanding Credit per Annum)

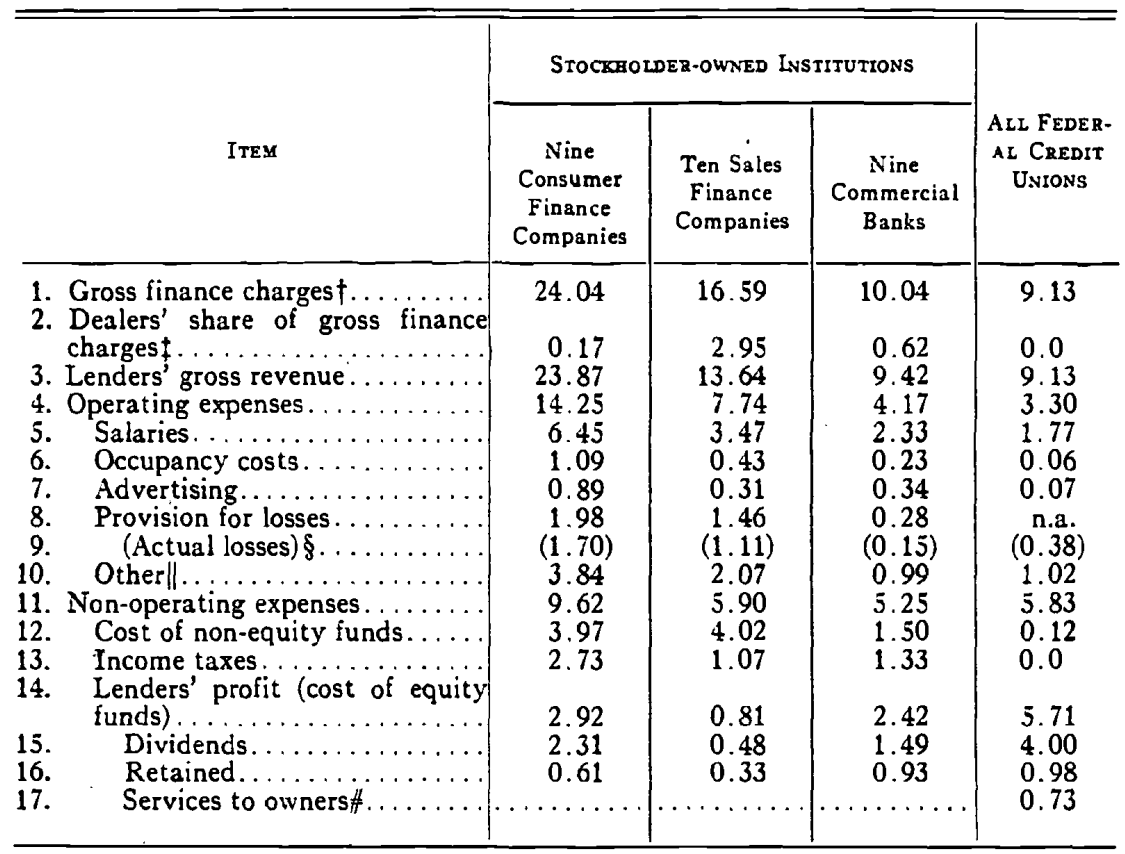

* Data for all types except federal credit unions are based on averages of individual company ratios. Ratios for federal credit unions are based on tabulations for all federal credit unions.

t Includes all finance charges and fees collected on consumer credit activities. Charges for insurance are not included, and the cost of freeinsurance provided to the borrower was deducted from the gross tinance charge.

\$ Dealers' share of gross finance charge represents the estimated difference between the gross finance charges and the charges which accrue to the financial institution that purchases the credit contract. The estimates of the dealer share are based on data from four large sales finance companies on new and used automobile contracts. No quantitative information was available for estimates of the dealer share on non-automotive contracts; hence no estimate of this was included. This share is known to be considerably less important than on automobile contracts, and in some cases the dealer does not receive a share of the charge.

8. Net of recoveries.

II This item includes a wide variety of expenses, such as travel, office supplies, legal fees, etc., that could not be obtained on a separate and uniform basis from all the sample companies.

\# Includes estimate of cost of servicing share accounts and cost of free life insurance provided shareholders. 
consumer; it was 29 per cent of the cost for consumer finance and for sales finance companies, 39 per cent for the commercial banks, and 64 per cent for credit unions. That is to say, 71 cents of the consumers' cost-of-credit dollar goes for expenses other than the cost of money in the case of consumer finance and sales finance companies, 61 cents in the case of banks, and 36 cents in the case of credit unions. The cost of equity (lenders' profit) came to 5 per cent of the total for sales finance companies, 12 per cent for consumer finance companies, 24 per cent for banks, and 63 per cent for credit unions. These results depend considerably, as is brought out below, on the relative amounts of equity funds used by the several types of lender.

\section{VARIATIONS IN OpERATING EXPENSES}

Comparison of the operating expenses for each type of company (Table 1) indicates that variations in these expenses account for the largest part of the differences in gross finance charges among the four types of institutions. A number of factors can be identified that contribute substantially to differences in operating costs among lenders: (1) the method of acquiring business, whether directly from the public or indirectly through dealers; (2) the character of the risks assumed; (3) the average size of contract; (4) the type of credit; and (5) institutional differences. Differences in the type of credit based on a purpose or collateral classification seem to contribute to differences in costs but are difficult to disentangle from elements of size and risk.

Consumer finance companies reported the highest operating cost per $\$ 100$ of credit and showed the highest cost in every category of expenditures (see Table 1). At the other extreme, credit unions showed the lowest cost on every item of expenditure except bad-debt losses and miscellaneous expenses. Commercial banks showed the lowest bad-debt losses and miscellaneous expenses.

Method of acquiring business.-Sales finance companies purchase most of their credit contracts from automobile dealers (indirect paper), while consumer finance companies and credit unions deal directly with the borrower (direct paper). Commercial banks obtain their receivables from both sources. The expenses incurred in the two methods of acquiring paper are very different.

Indirect financing frequently involves an arrangement whereby the dealer obtains a share of the finance charge. This share, which represents a part of the finance charge in automobile financing, amounted to an estimated 18 per cent of the gross charges at sales 
finance companies and 6 per cent at commercial banks. ${ }^{2}$ The difference in importance of the dealer's share at these two types of institutions reflects differences in the proportion of their receivables in automobile credit and the share acquired indirectly.

The income received by dealers from finance charges may be used to cover their costs in initiating the contract or the risks that they assume. It also gives them some flexibility in their pricing, and, under competitive market conditions, the dealer's share of the finance charge may be returned in part to credit buyers in the form of lower automobile prices. Thus gross finance charges shown in line 1 of Table 1 may overstate the effective finance charge to this extent.

The dealer's finance income may be offset in part by a reduction in the financing agency's operating expenses. The dealer absorbs part of the risk on recourse contracts, which carry the highest dealer finance charge share. The dealer also absorbs some of the cost of originating and accepting the application. However, separate data on operating expenses of direct versus indirect operations suggest that the savings in handling costs on indirect paper are relatively small. Expense data from a subsample of banks covered by the study showed only minor differences between the costs of direct and indirect automobile paper. This evidence is supported by data collected by the American Bankers Association that show a differential of only 10-15 per cent between the acquisition costs of an automobile contract purchased from a dealer and one acquired directly. ${ }^{3}$ These data show an average acquisition cost of $\$ 12.75$ per contract on direct loans and $\$ 11.50$ on indirect paper in 1957.

Direct-lending agencies, such as consumer finance companies and banks, must attract business from the public. This involves more advertising and a different promotional approach from that used in acquiring paper from dealers. The sample consumer finance companies spent 89 cents per $\$ 100$ of loans on advertising, while commercial banks spent 34 cents per $\$ 100$. The sales finance company figure, which was only slightly below that for commercial banks, includes some advertising for direct loans, as 20 per cent of their business was conducted directly with the public. The sales finance company with the largest advertising expense also had the largest directloan operation.

Direct-lending agencies must also provide facilities that are con-

2. See note $\ddagger$, Table 1 .

3. Material (in mimeographed form) distributed by the Instalment Credit Commission of the American Bankers Association to their membership. 
venient for the borrower. This not only requires additional offices but frequently more expensive locations. Consumer finance companies with loans of more than $\$ 100$ million had an average of 500 offices per company in mid-1960, while sales finance companies in the same size group averaged 200 offices per company. ${ }^{4}$ Occupancy costs amounted to $\$ 1.09$ per $\$ 100$ of consumer credit at sample consumer finance companies and to only 43 cents per $\$ 100$ at sales finance companies.

Although the sample banks obtained 75 per cent of their consumer credit business from the public, they reported lower average occupancy costs than did sales finance companies. This difference may reflect the ability of the bank to spread the cost of occupancy among its many functions. Most finance companies must allocate nearly all the cost of quarters to their consumer credit business.

The extremely low occupancy cost at credit unions reflects the free space that is frequently provided by the sponsors of these organizations and the nominal space requirements associated with part-time operations.

Risk.- Some of the costs arising from risks are indicated by losses charged off and by provision for losses. These measures differ from year to year, with provisions for losses exceeding actual losses in all but very bad years, but they show the same pattern of costs over time. Neither of these measures includes losses sustained by dealers under recourse agreements, nor do they reflect differentials in costs of investigation and collection associated with variations in credit quality. They represent, therefore, an incomplete measure of total costs of risks, and they understate the cost differential associated with different degrees of risk.

Loss figures, however, suggest the wide range of risks among lending institutions, as well as among individual companies. Actual losses charged off (net of recoveries) in 1959 varied from 15 cents per $\$ 100$ of credit at commercial banks to more than ten times that amount, or $\$ 1.70$ per $\$ 100$, at consumer finance companies. Sales finance companies showed losses of $\$ 1.11$ per $\$ 100$ and credit unions of 38 cents per $\$ 100$.

Many of the costs of handling higher-risk loans cannot be segregated from the rest of operating expenses. If all the costs associated with variations in risk could be isolated, risks would undoubtedly play a substantial part in explaining differences in operating costs among lenders.

Contract size.-The volume of work required in handling and 4. F. R. Pawley, "Survey of Finance Companies, Mid-1960," Federal Reserve Bulletin, October, 1961, pp. 1154-55. 
processing instalment contracts is more closely related to the number of contracts than to the dollar amounts involved. A subsample of banks, for example, handled thirty appliance contracts for every $\$ 10 ; 000$ in volume but only five automobile contracts for the same dollar volume. ${ }^{5}$ The cost of handling $\$ 100$ of appliance paper was accordingly much higher than the cost of handling the same dollar volume of automobile paper. Cost figures from these banks showed operating expenses of $\$ 7.40$ per $\$ 100$ for appliance paper and $\$ 3.09$ per $\$ 100$ for indirect automobile paper.

The average size of contracts acquired during the year varied among institutions from $\$ 436$ at consumer finance companies to $\$ 1,031$ at commercial banks (Table 2). These averages reflect the type of business conducted, as well as the size of contract by type of credit. The estimated average personal loan contract acquired by finance companies was only $\$ 431$, compared with the average indirect automobile contract of $\$ 1,875$ at commercial banks. The latter estimate includes both new- and used-car credit contracts.

Both the cost of acquiring new contracts during the year and the cost of servicing and handling old contracts are intermingled in the annual expense data obtained in this study. As a result, dividing annual expenses by the number of contracts acquired does not give a very good measure of the costs of acquiring an individual credit contract. Nor does dividing annual expenses by the number of outstanding contracts give a very good measure of the cost of handling and servicing credit contracts. However, such averages do give some indication of the influence of size of contract on costs. Estimates of the cost per outstanding contract, shown in the last column of Table 2, reveal that the percentage range of costs among different types of institutions is greatly reduced when costs are expressed per contract.

The high dollar cost per $\$ 100$ of credit of consumer finance companies is clearly related to the small average size of contract. The differences between operating costs at consumer finance companies and other lenders are sharply reduced when the comparison is based on the cost per outstanding contract rather than on costs per $\$ 100$ of credit. Consumer finance company costs per $\$ 100$ of credit are three and a half times those of banks and nearly twice those of sales finance companies, but their costs per outstanding contract are only one and a half times those of commercial banks and are smaller than those of sales finance companies.

Type of credit.-Data for commercial banks show a wide variation

5. These figures are based on data from a subsample of five of the total bank sample. 
in cost by type of loan (Table 2). Operating expenses on direct automobile paper were $\$ 2.84$ per $\$ 100$, compared with $\$ 7.40$ per $\$ 100$ on other goods paper. These differences reflect many elements, such as risk, contract size, the number of instalments, and others that cannot be identified from the data available. Such marked cost difierentials within the same institutional structure suggest that some of the varia-

TABLE 2

\section{ANNUAL OPERATING EXPENSES BY LENDING INSTITUTION AND SELECTED TYPES OF CREDIT, 1959}

(Dollars)

\begin{tabular}{|c|c|c|c|c|}
\hline \multirow{2}{*}{$\begin{array}{l}\text { TYPE OF INSTITUTION } \\
\text { (1) }\end{array}$} & \multirow{2}{*}{$\begin{array}{l}\text { COST PER } \\
\text { \$100 OP } \\
\text { CREDIT } \\
\text { OUTSTAND- } \\
\text { ING* } \\
(2)\end{array}$} & \multicolumn{2}{|c|}{$\begin{array}{l}\text { Average Size of } \\
\text { Contracts }\end{array}$} & \multirow{2}{*}{$\begin{array}{c}\text { Cost PER } \\
\text { CONIRACT } \\
\text { OUTSTAND } \\
\text { nNG } \\
\text { (5) }\end{array}$} \\
\hline & & $\begin{array}{l}\text { Acquired } \uparrow \\
\text { (3) }\end{array}$ & $\begin{array}{l}\text { Outstanding } \ddagger \\
\text { (4) }\end{array}$ & \\
\hline \multirow{3}{*}{$\begin{array}{l}\text { Nine consumer finance companies } \| \ldots \\
\text { Ten sales finance companies } \| \ldots \ldots \ldots \\
\text { Nine commercial banks } \| \ldots \ldots \ldots \ldots \\
\text { All federal credit unions } \ldots \ldots \ldots \ldots \ldots\end{array}$} & \multicolumn{4}{|c|}{ All Types of Credit } \\
\hline & $\begin{array}{r}14.25 \\
7.74 \\
4.17 \\
3.30\end{array}$ & $\begin{array}{r}436 \\
896 \\
1,031 \\
593\end{array}$ & $\begin{array}{l}346 \\
700 \\
723 \\
553\end{array}$ & $\begin{array}{l}49.30 \\
54.18 \\
30.15 \\
18.25\end{array}$ \\
\hline & \multicolumn{4}{|c|}{ Selected Types of Credit } \\
\hline 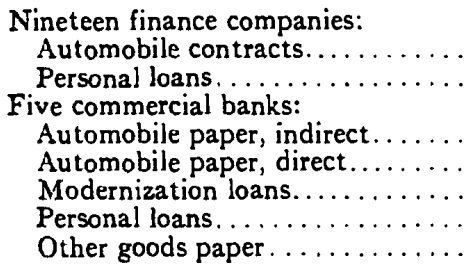 & $\begin{array}{l}3.09 \\
2.84 \\
3.49 \\
4.36 \\
7.40\end{array}$ & $\begin{array}{r}1,875 \\
1,692 \\
1,403 \\
714 \\
335\end{array}$ & $\begin{array}{r}1,181 \\
1,066 \\
909 \\
468 \\
220\end{array}$ & $\begin{array}{l}36.49 \\
30.27 \\
31.72 \\
20.40 \\
16.28\end{array}$ \\
\hline
\end{tabular}

* Data for group totals from Table 1, line 4.

t Obtained by dividing the dollar volume of contracts acquired by the number of contracts acquired during the year.

I Obtained by dividing the amount outstanding (average of beginning and end of year) by the number of contracts outstanding (average of beginning and end of year).

$\$$ Obtained by multiplying the cost per $\$ 100$ of credit (col. 2) by the average outstanding contract (col. 4); equivalent to total operating expenses divided by average number of contracts outstanding at beginning and end of year.

4 Average balances of contracts acquired and outstanding were obtained by weighting the average balances by type of credit by estimates of the number of contracts acquired and outstanding.

Estimates of the cost of automobile contracts and of all other contracts were obtained by assuming that tbe cost per $\$ 100$ for automobile contracts was the same at both consumer and sales finance companies and that the cost per $\$ 100$ for all other contracts (largely personal loans) pas also the same at each type of institution. That is, it was assumed that the over-all average costs per $\$ 100$ differ only because of the difference in the proportions of auto and other contracts outstanding. If $a$ is the cost per $\$ 100$ of automobile contracts and $b$ the cost per $\$ 100$ of other contracts, and these are weighted by the relative proportions of amounts outstanding, then $0.019 a+0.981 b=\$ 14.25$ (for nine consumer fance companies), and $0.729 c+0.271 b=\$ 7.74$ (for ten sales finance coropanies). Hence $a=\$ 5.26$ and $b=\$ 14.42$. 
tion in costs among different types of institutions can be attributed to variations in the type of credit they extend.

The cost differential on the same type of business between types of institution is sizable. The cost of providing personal loans at finance companies was nearly $\$ 10$ per $\$ 100$ more than at commercial banks and nearly $\$ 11$ per $\$ 100$ more than at credit unions. Part, but not all, of these differentials can be explained by differences in average size of loan. The cost per contract was higher at finance companies than at other institutions, but the percentage spread was much smaller than the range in costs per dollar.

Institutional differences. - The expenses of all lenders are shaped to some extent by the legal and institutional framework within which they operate. The operating expenses of credit unions, for example, are reduced in a number of ways by their co-operative organization. Much of the clerical work is done by the voluntary help of the members, sometimes during time paid for by the sponsoring organization. Quarters are frequently provided by the sponsoring organization, and promotional expenses are usually nominal because of the limited membership. A quantitative comparison of the savings that result from these advantages is not possible. A rough indication of the nature of the differences is obtained by comparing the credit-union costs with those of the sample of commercial banks. Commercial bank salary costs were a third larger, and their occupancy and advertising expenses were four times larger than those of credit unions.

The business conducted by consumer finance companies resembles that of credit unions in many ways. Both types of institutions deal primarily in relatively small personal loans, but their expenses differ widely. Salary expenses of consumer finance companies were three and a half times those of credit unions. Their occupancy costs were seventeen times larger, and their advertising expenses were twelve times larger.

The institutional advantages and disadvantages of other types of companies are less obvious and hence more difficult to detect. Regulations that specify operating procedures or legal restrictions that limit the size of loan may adversely affect expense ratios. The impact of regulatory provisions on consumer finance companies probably provides the best illustration of the cost differential arising from legal and administrative supervision. The adverse effect of their small loan size on expenses has already been discussed. Administrative provisions, such as those requiring the issuance of new certificates and the cancellation of old ones upon the renewal of the loan and those speci- 
fying the daily computation of interest charges, add to the high cost of their operations.

Individual company variation. - As would be expected, individual companies of each type of institution differ considerably from an average for all companies. Many of the factors explaining differences in operating expense among different types of institutions apply to individual institutions. They operate in different markets and assume different credit risks, specialize in different types of credit, and work with varying degrees of efficiency.

A comparison of expense data for companies that show extremes in costs reveals considerable overlapping among types of institutions. The lowest-cost consumer finance company had lower operating expenses than did the highest-cost sales finance company. The lowestcost sales finance company had lower costs than did the highest-cost commercial bank, and the bank with the lowest cost fell below the average for all federal credit unions.

\section{VARIATIONS IN NON-OPERATING EXPENSES}

Non-operating costs include the cost of non-equity funds, provisions for income taxes, and the lenders' profit. Differences in the costs among the four types of institutions reflect primarily different sources of funds and, in the case of federal credit unions, exemption from income taxes (Table 1). These costs contributed significantly to variations in gross finance charges among the four types of institutions, although they were less important than operating expenses in explaining these variations.

A number of factors contributed to differences in total non-operating costs and to the distribution of these costs: (1) the rate paid for funds, in both the equity and non-equity markets; (2) sources and uses of funds: the proportion of funds supplied by owners and the proportion of resources held idle in non-earning assets; (3) cost of non-equity funds; (4) effective income tax rates; (5) lender's profit.

Rate paid for funds. - The institutions covered by this paper draw their funds from the entire spectrum of credit markets and attract funds with a wide range of rates and terms. They do not all have access to the same markets, however, and their costs vary accordingly.

Commercial banks have exclusive access to demand deposits as a source of funds. They do not pay interest on these deposits, but they assume a substantial part of the costs of handling and servicing these accounts. In addition, they bear hidden costs that cannot be measured, such as loss of earnings that result from holding legal reserves 
and from the low return on secondary reserves. The cost estimates of demand deposits are based on cost-accounting records, and information was not available from the reporting banks to permit a separation of the costs of handling demand and time deposits. ${ }^{6}$ The combined administrative cost of handling deposits at the sample banks, net of service charges, amounted to 70 cents per $\$ 100$ of deposits (Table 3).

Both commercial banks and credit unions have access to the market for savings accounts. The cost of these accounts includes interest payment, as well as handling costs. The savings market covered by commercial banks and credit unions cannot be equated, however, be-

TABLE 3

AVERAGE COSTS OF FUNDS, 1959

(Per Cent of Outstanding Balances)

\begin{tabular}{|c|c|c|c|c|}
\hline \multirow{2}{*}{ I TEM } & \multirow{2}{*}{$\begin{array}{l}\text { DEat AND } \\
\text { DEposits }\end{array}$} & \multirow{2}{*}{$\begin{array}{l}\text { Total NoN- } \\
\text { EQUITY } \\
\text { Funds* }\end{array}$} & \multicolumn{2}{|c|}{ EQUITY FUNDS } \\
\hline & & & $\begin{array}{l}\text { Net Profits } \\
\text { to Net Worth }\end{array}$ & $\begin{array}{l}\text { Dividends } \\
\text { to Net Worth }\end{array}$ \\
\hline $\begin{array}{l}\text { Nine commercial banks, total...... } \\
\text { Interest on time deposits......... } \\
\text { Cost of handling deposits. . . }\end{array}$ & $\begin{array}{l}1.3 \dagger \\
2.7 \\
0.7\end{array}$ & $1.2 \dagger$ & 7.6 & 4.5 \\
\hline $\begin{array}{l}\text { Nine consumer finance companies.. } \\
\text { Ten sales finance companies........ } \\
\text { All federal credit unions. ......... }\end{array}$ & $\begin{array}{l}5.0 \\
4.5 \\
3.8\end{array}$ & $\begin{array}{l}4.6 \\
4.2 \\
3.1\end{array}$ & $\begin{array}{r}12.1 \\
10.3 \\
5.0\end{array}$ & $\begin{array}{l}7.7 \\
5.9 \\
3.4\end{array}$ \\
\hline
\end{tabular}

* Total non-equity funds include liabilities on which no interest charges are incurred. The inclusion of these amounts reduces the cost of funds as a percentage of the amounts involved.

$\dagger$ Includes interest on debt.

cause of the greater security offered by the commercial banks through deposit insurance and the debt status of their deposits. Savings accounts placed in credit unions must share many of the risks of equity capital. The sample commercial banks paid an average of 2.7 per cent on their time deposits in 1959, in contrast to cash payments of 3.4 per cent by federal credit unions. ${ }^{7}$ In addition, the total cost of share accounts at credit unions includes the cost of servicing the accounts, retained earnings, and the costs of free insurance provided for share-

6. An alternate method of estimating the cost of funds to commercial banks would require an estimate of the opportunity cost of credit to the consumer credit department of a bank. The cost-accounting approach was chosen to avoid the arbitrary aspects of an opportunity-cost estimate.

7. Insured commercial banks, on the average, paid a slightly lower figure (2.4 per cent) in 1959 (Annual Report of the Federal Deposit Insurance Corporation for 1960 [Washington, 1961], pp. 154-55). 
holders. The total cost of the shareholders' funds in this broad view averaged 5 per cent.

All four types of financial institutions obtained some funds from various debt markets. Commercial banks borrow from other banks and from Federal Reserve banks. Since they typically pay off such borrowings before statement dates, the data for year-end dates seldom indicate the normal extent of this type of indebtedness. Rates on funds obtained in these markets correspond closely to Federal Reserve discount rates, which ranged between 3 and 4 per cent in 1959 . Credit unions borrow relatively small amounts from banks and other credit unions. They paid an average of 3.8 per cent on their debt in 1959.

Finance companies obtain their funds from banks and from public markets. The large finance companies have access to nearly all the public markets, both long- and short-term. Some of them place commercial paper directly with financial and non-financial corporations, others sell their paper through dealers. They raise long-term funds either in the form of subordinated or senior debt in the capital markets and by direct placement. In 1959 the sample of sales finance companies paid an average of 4.5 per cent for their debt funds obtained in all markets, while the consumer finance companies paid an average of 5 per cent.

Variations in the rate paid for total non-equity funds depend on the credit rating of the individual institution, the sources used, the mix between long- and short-term funds, and the importance of noninterest-bearing liabilities. The average rate paid by individual sales finance companies varied from 3.7 to 4.7 per cent, and that paid by consumer finance companies varied from 4.0 to 5.6 per cent.

Since most banks require finance companies to maintain compensating balances, the average rate on finance company indebtedness understates the total costs. The added cost appears in this study as part of the costs of idle funds, since the compensating balances are included as bank balances. ${ }^{8}$ This treatment is consistent with that used for bank reserves against deposits.

Equity funds used by banks and finance companies are obtained from local and national markets. The rate that must be earned on the book value of net worth to attract new funds and the dividends that must be paid depend on the investor's attitude toward a particular company or type of business. The ratio of net profit to net worth

8. The cost of non-equity funds expressed as a percentage of consumers receivables (Table 1, line 12) reflects the cost of compensating balances, in that the total cost of funds is related to the proportion of funds that is actually invested in receivables. 
varied from 12.1 per cent for the sample of consumer finance companies to 7.6 per cent for banks (Table 3 ). Individual company variations in the return on net worth were sizable.

Sources and uses of funds. - The proportion of total resources obtained from non-equity sources has an important impact on both the total cost of funds and the return to the lender. The percentage of non-equity funds used varied from 90 at commercial banks to 3 at credit unions (Table 4 ). The sample sales finance companies obtained 84 per cent and the consumer finance companies about 7,5 per cent of their funds from non-equity sources.

\section{TABLE $4^{*}$}

SOURCES AND USES OF FUNDS, 1959

(Per Cent)

\begin{tabular}{|c|c|c|c|c|}
\hline Item & $\begin{array}{c}\text { Nine } \\
\text { Consumer } \\
\text { Finance } \\
\text { Companies }\end{array}$ & $\begin{array}{l}\text { Ten Sales } \\
\text { Finance } \\
\text { Companies }\end{array}$ & $\begin{array}{l}\text { Nine } \\
\text { Commercial } \\
\text { Banks }\end{array}$ & $\begin{array}{c}\text { All } \\
\text { Federal } \\
\text { Credit } \\
\text { Unions }\end{array}$ \\
\hline 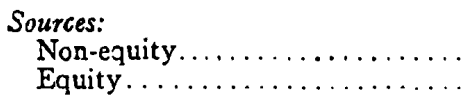 & $\begin{array}{l}74.6 \\
25.4\end{array}$ & $\begin{array}{l}84.2 \\
15.8\end{array}$ & $\begin{array}{r}90.2 \\
9.8\end{array}$ & $\begin{array}{r}2.6 \\
97.4\end{array}$ \\
\hline Total. & 100.0 & 100.0 & 100.0 & 100.0 \\
\hline $\begin{array}{l}\text { Uses: } \\
\quad \text { Earning assets, net......... } \\
\quad \text { Non-earning assets...... }\end{array}$ & $\begin{array}{l}87.2 \\
12.8\end{array}$ & $\begin{array}{l}88.0 \\
12.0\end{array}$ & $\begin{array}{l}77.1 \\
22.9\end{array}$ & $\begin{array}{r}92.2 \\
7.8\end{array}$ \\
\hline Total. & 100.0 & 100.0 & 100.0 & 100.0 \\
\hline
\end{tabular}

- Based on averages of beginning- and end-of-year dates.

Since a share of the funds used in any lending operation must be allocated to cash balances and other non-earning assets, the cost of such funds reduces the return available from earning assets. Many accountants deduct the amount of non-earning assets from total debt in computing the effective rate paid for funds used in their lending operations. Since the proportion of idle funds differed so widely from one type of institution to another, the costs of non-earning assets were treated in this study as a separate item of expense. In many cases, however, part of the expense of non-earning assets could be treated as a cost of non-equity funds. The large legal reserves required of banks could be considered in part as a cost of deposits, and the compensating balances that banks require of finance companies could be considered as part of the cost of borrowing. 
The proportion of resources held in non-earning forms varied from 23 per cent for the sample of banks to 8 per cent at federal credit unions. Finance companies of both types held about 12-13 per cent of their resources in non-earning forms (Table 4).

Cost of non-equity funds. - The cost of non-equity funds used in consumer credit varied between $\$ 4.02$ per $\$ 100$ of credit at sales finance companies to 12 cents per $\$ 100$ at federal credit unions (Table 1). These differences reflected variations in the rates paid for these funds, in the proportion of non-equity funds used for consumer credit, and in the burden of non-earning assets.

The average cost of non-equity funds to lenders falls within a rela-

TABLE 5

COST OF NON-EQUITY FUNDS, 1959

(Per Cent of Outstanding Balances)

\begin{tabular}{|c|c|c|c|c|}
\hline Cost of Non-Equity Funds to & $\begin{array}{c}\text { Nine } \\
\text { Consumer } \\
\text { Finance } \\
\text { Companies }\end{array}$ & $\begin{array}{l}\text { Ten Sales } \\
\text { Finance } \\
\text { Companies }\end{array}$ & $\begin{array}{l}\text { Nine } \\
\text { Commercial } \\
\text { Banks }\end{array}$ & $\begin{array}{c}\text { All } \\
\text { Federal } \\
\text { Credit } \\
\text { Unions }\end{array}$ \\
\hline $\begin{array}{l}\text { Total debt and deposits. } \ldots \ldots \ldots \ldots \ldots \\
\text { Total non-equity funds.............. }\end{array}$ & $\begin{array}{l}5.0 \\
4.6\end{array}$ & $\begin{array}{l}4.5 \\
4.2\end{array}$ & $\begin{array}{l}1.3 \\
1.2\end{array}$ & $\begin{array}{l}3.8 \\
3.1\end{array}$ \\
\hline $\begin{array}{l}\text { Non-equity funds minus non-earning } \\
\text { assets } \ldots \ldots \ldots \ldots \ldots \ldots \ldots \ldots \ldots \ldots \ldots \\
\text { Consumer assets } \dagger \ldots \ldots \ldots \ldots \ldots \ldots\end{array}$ & $\begin{array}{l}5.8 \\
4.0\end{array}$ & $\begin{array}{l}4.8 \\
4.0\end{array}$ & $\begin{array}{l}1.7 \\
1.5\end{array}$ & $\stackrel{*}{*}$ \\
\hline
\end{tabular}

* Non-earning assets exceed non-equity funds at federal credit unions.

† Table 1 , line 13 .

tively narrow range except for commercial banks (Table 3 ). Finance companies and credit unions paid between 3.1 and 4.6 per cent per $\$ 100$. The banks, however, obtained their non-equity funds for an average of 1.2 per cent.

The cost of non-equity funds used in consumer credit includes the burden of providing part of the funds used in non-earning forms. Many companies deduct their non-earning assets from non-equity funds in computing the effective rate paid for funds used in lending operations. The difference between the rate calculated in this way and the rate on non-equity funds is a rough measure of the cost of idle balances. This cost is relatively most important at commercial banks, where idle funds add about 40 per cent to the effective cost of money used in lending (Table 5).

Since the average cost of non-equity funds used in consumer lending also depends on the extent to which these funds are used, the pro- 
portion of non-equity to equity funds affects the total cost of such funds as a percentage of consumer receivables. The extremely low cost of non-equity funds at credit unions merely reflects the minor importance of such funds in their total resources, while the high cost at finance companies reflects the importance of non-equity funds.

The various elements entering into the cost of non-equity funds as a part of the gross finance charge are summarized in Table 5. Although the average rate paid for non-equity funds by consumer finance companies was higher than that paid by sales finance companies, the net cost to the consumer was about the same because of the difference in the share of equity funds used. The low cost of nonequity funds to consumers at commercial banks, despite the importance of these funds in their total resources, reflects the lower cost of these funds to the bank.

Income taxes.-The most striking variation in income taxes arises from the tax exemption of credit unions as co-operative organizations. The other three types of institutions are all subject to income taxes.

Among the three taxpaying institutions, the sample of consumer finance companies reported the highest tax cost- $\$ 2.73$ per $\$ 100-$ and sales finance companies the lowest $-\$ 1.07$ per $\$ 100$. The differences reflected primarily their earnings before tax. The effective rate on pretax earnings averaged 45 per cent at all three types. Although this percentage varied slightly by type of institution, the differences for any one year are not a reliable indication because they may include adjustments for over- or under-accruals in previous years or other special tax adjustments.

Cost of equity.-The cost of equity funds (lender's profit) in consumer credit ranged from 81 cents per $\$ 100$ of consumer credit at sales finance companies to about seven times that amount, or $\$ 5.71$ per $\$ 100$, at federal credit unions (Table 1 ). These differences reflect differences in the ability of lenders to convert the return from their lending into a satisfactory return on equity and the return from consumer credit that has to be maintained to provide an adequate return on net worth to attract and hold funds in the business. The total cost of equity funds to the consumer falls well below return on equity funds. For example, consumers paid 81 cents per $\$ 100$ for the use of equity funds at sales finance companies in 1959 , yet the return on net worth (net profits to net worth) at these companies was $\$ 10$ per $\$ 100$. Before taxes and interest payments, sales finance companies earned a net operating income from consumer credit of 5.9 per cent and were able to earn 18 per cent on their net worth. 
The principal device for enlarging the return from consumer lending lies in the financial advantage or leverage of the use of non-equity funds. If the lender can earn a higher return on his resources than he pays for the funds, the differential profit accrues to the owners and enlarges the return. This advantage permits the lender to charge the consumer less for the use of equity than he has to earn to attract risk capital in to the business.

All stockholder-owned institutions depend heavily on the financial advantage of non-equity funds to produce a satisfactory return on equity from the relatively low rates charged to the consumer (Table 6). Leverage was highest at commercial banks, where 83 per cent of

TABLE $6^{*}$

FACTORS IN LENDER'S PROFITS

(Per Cent of Outstanding Balances)

\begin{tabular}{|c|c|c|c|c|}
\hline Item & $\begin{array}{l}\text { Nine } \\
\text { Consumer } \\
\text { Finance } \\
\text { Companies }\end{array}$ & $\begin{array}{l}\text { Ten Sales } \\
\text { Finance } \\
\text { Companies }\end{array}$ & $\begin{array}{c}\text { Nine } \\
\text { Commercial } \\
\text { Banks }\end{array}$ & $\begin{array}{c}\text { All } \\
\text { Federal } \\
\text { Credit } \\
\text { Unions }\end{array}$ \\
\hline 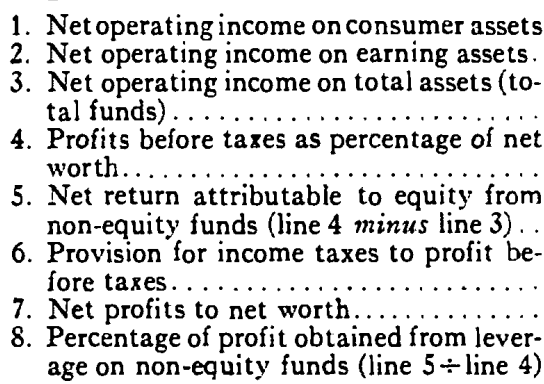 & $\begin{array}{r}9.6 \\
10.4 \\
9.1\end{array}$ & $\begin{array}{l}11.6 \\
42.5 \\
10.3\end{array}$ & $\begin{array}{l}5.3 \\
3.4 \\
2.5\end{array}$ & $\begin{array}{l}5.8 \\
5.3\end{array}$ \\
\hline 、 & \multicolumn{4}{|c|}{$\begin{array}{l}\text { Derivation of Net Return } \\
\text { to Equity from Non-Equity (Line 5) }\end{array}$} \\
\hline $\begin{array}{l}\text { a) Net operating income on total assets } \\
(\text { line } 3) \ldots \ldots \ldots \ldots \ldots \ldots \ldots \ldots \ldots \\
\text { minus }\end{array}$ & 9.1 & 6.3 & 2.5 & 4.9 \\
\hline b) Cost of non-equity funds. . $\begin{array}{c}\text { equals } \\
\text { equan }\end{array}$ & 4.6 & 4.2 & 1.2 & 3.1 \\
\hline $\begin{array}{l}\text { c) Net return from non-equity funds..... } \\
\text { times }\end{array}$ & 4.5 & 2.1 & 1.3 & 1.8 \\
\hline $\begin{array}{l}\text { d) Leverage coefficient (ratio of non-equity } \\
\text { to equity funds)...................... } \\
\text { approximates }\end{array}$ & 3.0 & 5.6 & 9.6 & 0.03 \\
\hline $\begin{array}{l}\text { e) Net return to equity from non-equity } \\
\text { funds per dollar of net worth (line 5)... }\end{array}$ & 13.5 & 11.8 & 12.5 & 0.05 \\
\hline
\end{tabular}

* Items 1 and 7 are from Tables 1 and 3 , respectively.

$\dagger$ Based on unrounded data. 
the return on equity came from the use of non-equity funds; the next highest was at sales finance companies; and the lowest was at consumer finance companies, where 59 per cent of the return was from this source. The high cost of equity funds to the credit-union borrowers can be explained almost entirely by the absence of any financial advantage from the use of debt.

All four types of institutions invested part of their resources in non-consumer activities. Commercial banks and credit unions showed a lower return from all earning assets than from consumer assets alone (Table 6, lines 1 and 2). At the sample commercial banks, the average net operating income on all earning assets was 3.4 per cent, or 1.9 percentage points less than the yield on consumer assets. At the credit unions the net operating income on all earning assets was onehalf a percentage point below the return on consumer credit. Consumer credit activities therefore carry more than a proportionate share in the total cost of equity funds at these institutions.

The sample finance companies, however, earned a higher average return (1.3 percentage points higher) on their total earning assets than on their consumer assets. Part of this difference may reflect the difficulty of adjusting the sales finance cost data to allow properly for the cost of non-consumer credit. Provision was made for the cost of insurance and other non-consumer operations, but such costs are difficult to segregate, and some of the related costs may have been underestimated.

Profitable alternatives for use of funds permit some flexibility in the pricing of consumer credit. To the extent that the higher earnings rate on non-consumer credit arises from activities related to consumer lending, such as credit life insurance or insurance on the collateral to the loan, the lender can offer lower rates on credit. In such cases, part of the cost of consumer credit may be absorbed in other activities and paid for in the form of higher prices for the related items. This type of substitution is common in retail operations, where part of the cost of credit may be absorbed in the profit of the article sold. The possibility of such a substitution makes an exact determination of the total cost of credit to consumers virtually impossible.

Comparison by type of institution.-Non-operating expenses on consumer credit were highest at the sample of consumer finance companies. Their high cost compared to other types of institutions refiected their tax disadvantage relative to credit unions; the high cost of their non-equity funds; their small ratio of non-equity funds to total resources, which, together with their high cost of funds, resulted 
in the lowest leverage among the stockholder-owned institutions; and the high cost of their equity funds.

At the other extreme, the commercial bank sample had the lowest non-operating costs. Their costs were $\$ 4.40$ per $\$ 100$ below those of the consumer finance companies and reflected primarily the low cost of their non-equity funds, and their high ratio of non-equity funds to total resources, which, together with their low cost of funds, gave them the largest advantage from leverage.

Federal credit unions were the second lowest in non-operating costs. Their position relative to finance companies stemmed primarily from their exemption from income taxes and their inexpensive source of equity funds from the savings markets.

The sample of sales finance companies showed non-operating costs of $\$ 2.70$ per $\$ 100$ less than those of the consumer finance companies, despite the many similarities in their operations. They were able to achieve this cost differential largely because: (1) they were able to supplement their earnings from consumer credit by a high rate of return on their other activities; (2) they obtained a slightly better rate on non-equity funds; (3) they had a high ratio of non-equity funds to total resources and hence were able to show greater leverage; and (4) their cost of equity funds was smaller.

\section{Profits}

The lender's profits are a necessary cost to consumers as long as they are no larger than necessary to attract and hold equity funds in the industry. The profits from consumer credit are considered "normal" if they are similar to those of their competitors for equity funds. Such comparisons are difficult because of a wide variety of factors that enter into the market evaluation of equities. The rate that any company or any type of institution must earn depends on the investor's appraisal of the risks involved, potential growth, and his attitude toward the industry and the particular company.

The extremes in the market for equity funds are illustrated by the difference between the sources of funds for credit unions and those for consumer finance companies. Credit unions offer a high degree of liquidity with some risk, while the stock of a finance company may offer less liquidity and greater risk. Investors in the latter case must be compensated by a higher return.

The average net profit to the book value of net worth in 1959, shown in Table 6, ranged from 5 per cent at federal credit unions to 7.6 per cent at the sample commercial banks, 10.3 per cent at the 
sales finance companies, and 12.1 per cent at the consumer finance companies. Although these averages vary with the gross finance charges at these institutions, this does not imply excessive profits in any case. The normal return would be expected to vary with liquidity, risk, growth potential, and investor appeal of the different types of institutions.

All the profit rates for the stockholder-owned financial institutions fell well within the range of rates at manufacturing corporations. ${ }^{9}$ The average profit to net worth for the samples of stockholder-owned companies covered by the study was 9.9 per cent in 1959. This compares with an average for all manufacturing corporations of 10.4 per cent. The profit rates for a number of industry groups, including the chemical, drug, and tobacco industries, were higher than the highest rate for institutions covered by the study. These comparisons cannot necessarily establish that the profits of consumer lending are normal, but they place consumer credit institutions in an intermediate position among their competitors for equity capital.

\section{Summary}

Consumer credit is supplied in many forms, ranging from small, unsecured loans to long-term contracts of thousands of dollars protected by valuable collateral. It is sometimes provided on a personalized retail basis and sometimes handled in large-scale bulk operations. This study of the operations of nine commercial banks, ten sales finance and nine consumer finance companies, and all federally chartered credit unions reveals a wide range in the cost of providing consumer credit in 1959.

Average finance charges on the consumer credit provided by these groups of institutions varied from $\$ 24$ to $\$ 9$ per $\$ 100$ of credit outstanding. Most of the variation in finance charges was traced to differences in operating expenses. The profits of the stockholder-owned institutions averaged 9.9 per cent of net worth, which was within the range of profits recorded by manufacturing corporations.

Operating expenses were directly related to finance charges and ranged from $\$ 3.30$ to $\$ 14.25$ per $\$ 100$ of outstanding credit. Many factors contributed to this spread. The method of acquiring business, whether it was obtained directly from the public or indirectly from dealers, caused variation in advertising and occupancy expenses. Differences in the character of risks were reflected in loss ratios ranging

9. Federal Trade Commission and Securities and Exchange Commission, Quarterly Financial Report for Manufacturing Corporations (first quarter, 1960), pp. 12-27. 
from 15 cents per $\$ 100$ of outstanding credit at commercial banks to a figure eleven times as large at consumer finance companies. Variations in the size of credit contracts resulted in differences in the number of contracts that had to be handled for a given dollar volume of credit and in the cost per $\$ 100$ of credit outstanding. It was estimated that the sample consumer finance companies, which represented the smallest average contract size, handled 23 contracts for each $\$ 10,000$ of new business, while commercial banks handled less than half that number. Legal provisions controlling operating practices and assistance provided by members and sponsors of credit unions added to cost differentials.

Smaller but significant differences in the cost of providing consumer credit were traced to the methods of financing and to variations in income tax provisions. The four institutions obtained equity and non-equity funds in nearly all the major credit markets. The cost of non-equity funds ranged from 1.2 to 4.6 per cent. The effectiveness with which the institutions were able to use resources and the extent to which they were able to obtain debt financing affected the cost of money used in providing credit to consumers. 


\section{NATIONAL BUREAU OCCASIONAL PAPERS 1940-62}

*1 Manufacturing Output, 1929-1937

Solomon Fabricant

1940,28 pp.

*2 National Income, 1919-1938

Simon Kuznets

$1941,32 \mathrm{pp}$.

* 3 Finished Commodities since 1879: Output and Its Composition William H. Shaw

$1941,49 \mathrm{pp}$.

*4 The Relation between Factory Employment and Output since 1899 Solomon Fabricant

1941,39 pp.

*5 Railway Freight Traffic in Prosperity and Depression Thor Hultgren

1942, $51 \mathrm{pp}$.

*6 Uses of National Income in Peace and War Simon Kuznets

1942, 42 pp.

*7 Productivity of Labor in Peace and War Solomon Fabricant

1942,28 pp.

*8 The Banking System and War Finance Charles R. Whittlesey

$1943,53 \mathrm{pp}$.

*9 Wartime 'Prosperity' and the Future Wesley C. Mitchell

1943, 40 pp.

10 The Effect of War on Business Financing: Manufacturing and Trade, World War $I$

Charles H. Schmidt and Ralph A. Young

1943,95 pp., $50 \phi$

*11 The Effect of War on Currency and Deposits

Charles R. Whittlesey

$1943,50 \mathrm{pp}$.

12 Prices in a War Economy: Some Aspects of the Present Price Structure of the United States

Frederick C. Mills

1943,102 pp., 50ф

*13 Railroad Travel and the State of Business Thor Hultgren

1943,35 pp.

14 The Labor Force in Wartime America

Clarence D. Long

1944,73 pp., $50 \%$

15 Railway Traffic Expansion and Use of Resources in World War II Thor Hultgren

1944, 31 pp., $35 \phi$

* 16 British and American Plans for International Currency Stabilization

J. H. Riddle

$1943,42 \mathrm{pp}$.

17 National Product, War and Prewar Simon Kuznets

1944,54 pp., 506

18 Production of Industrial Materials in World Wars 1 and II Geoffrey H. Moore

1944, 81 pp., 506

19 Canada's Financial System in War Benjamin $\mathrm{H}$. Higgins

1944,82 pp., 506

*20 Nazi War Finance and Banking Otto Nathan

$1944,100 \mathrm{pp}$.

"Out of Print 
*21 The Federal Reserve System in Wartime Anna Youngman

$1945,67 \mathrm{pp}$.

"22 Bank Liquidity and the War Charles R. Whittlesey

$1945,86 \mathrm{pp}$.

*23 Labor Savings in American Industry, 1899-1939 Solomon Fabricant $1945,56 \mathrm{pp}$.

24 Domestic Servants in the United States, 1900-1940 George J. Stigler 1946, 44 pp., 50 ధ

*25 Recent Developments in Dominion-Provincial Fiscal Relations in Canada J. A. Maxwell $1948,62 \mathrm{pp}$.

*26 The Role of Inventories in Business Cycles Moses Abramovitz

$1948,26 \mathrm{pp}$.

27 The Structure of Posiwar Prices

Frederick C. Mills

1948,66 pp., $75 \zeta$

28 Lombard Street in War and Reconstruction Benjamin H. Higgins

1949,115 pp., $\$ 1.00$

*29 The Rising Trend of Government Employment Solomon Fabricant $1949,30 \mathrm{pp}$

30 Costs and Returns on Farm Mortgage Lending by Life Insurance Companies, 1945-1947

R. J. Saulnier

1949,55 pp., $\$ 1.00$

*31 Statistical Indicators of Cyclical Revivals and Recessions

Geoffrey H. Moore

$1950,96 \mathrm{pp}$.

*32 Cyclical Diversities in the Fortunes of Industrial Corporations Thor Hultgren

$1950,34 \mathrm{pp}$.

33 Employment and Compensation in Education

George J. Stigler

1950,77 pp., $\$ 1.00$

34 Behavior of Wage Rates during Business Cycles

Daniel Creamer

1950,66 pp., $\$ 1.00$

35 Shares of Upper Income Groups in Income and Savings Simon Kuznets

1950,68 pp., $\$ 1.00$

36 The Labor Force in War and Transition: Four Countries Clarence $D$. Long

1952.61 pp., $\$ 1.00$

37 Trends and Cycles in Corporate Bond Financing W. Braddock Hickman

1952, 37 pp., $75 €$

*38 Productivity and Economic Progress

Frederick C. Mills

$1952,36 \mathrm{pp}$.

"39 The Role of Federal Credit Aids in Residential Construction Leo Grebler

1953, 76 pp.

"40 Transport and the State of Trade in Britain Thor Hultgren

$1953,126 \mathrm{pp}$.

41 Capital and Output Trends in Manufacturing Industries, 1880-1948

Daniel Creamer

1954, 104 pp.

Out of Print 
42 The Share of Financial Intermediaries in National Wealth and National Assets, 1900-1949

Raymond W. Goldsmith

1954,120 pp., $\$ 1.50$

*43 Trends and Cycles in Capital Formation by United States Railroads, 1870-1950 Melville J. Ulmer

$1954,70 \mathrm{pp}$.

44 The Growth of Physical Capital in Agriculture, 1870-1950

Alvin S. Tostlebe

1954,104 pp., $\$ 1.25$

.45 Capital and Output Trends in Mining Industries, 1870-1948

Israel Borenstein

1954,81 pp., $\$ 1.00$

46 Immigration and the Foreign Born

Simon Kuznets and Ernest Rubin

1954,119 pp., $\$ 1.50$

*47 The Ownership of Tax-Exempt Securities, 1913-1953

George E. Lent

$1955,150 \mathrm{pp}$.

*48 $A$ Century and a Half of Federal Expenditures

M. Slade Kendrick

$1955,112 \mathrm{pp}$.

49 The Korean War and United States Economic Activity, 1950-1952

Bert G. Hickman

1955,72 pp., 754

50 Agriculture Equipment Financing

Howard G. Diesslin

1955,116 pp., $\$ 1.25$

51 Interest as a Source of Personal Income and Tax Revenue

Lawrence $H$. Seltzer

1955,82 pp., $\$ 1.25$

52 Resource and Output Trends in the United States since 1870

Moses Abramovitz

1956, 23 pp., 504

*53 Productivity Trends: Capital and Labor

John W. Kendrick

$1956,23 \mathrm{pp}$

54 Bank Stock Prices and the Bank Capital Problem David Durand

1957,76 pp., $\$ \$ 1.00$

55 Some Obeservations on Soviet Industrial Growth G. Warren Nutter

1957,12 pp., 504

56 Distribution of Union Membership among the States, 1939 and 1953

Leo Troy

1957,40 pp., $75 \phi$

57 Electronic Computers and Business Indicators

Julius Shiskin

1957,52 pp., $\$ 1.00$

58 Federal Lending: Its Growth and Impact

A summary, prepared by the National Bureau's editorial staff, of Federal Lending and Loan Insurance, by R. J. Saulnier, Harold G. Halcrow and Neil H. Jacoby

1957,56 pu., $\$ 1.00$

59 Corporate Bonds: Quality and Investment Performance

W. Braddock Hickman

1957,43 pp., $75 \phi$

60 The Postwar Rise of Mortgage Companies

Saul B. Klaman

1959,117 pp., $\$ 1.50$

61 Measuring Recessions

Geoffrey $\mathrm{H}$. Moore

1958,57 pp., $\$ 1.00$

62 The Demand for Currency Relative to Total Money Supply Phillip Cagan

1958,37 pp., $75 \phi$

'Out of Print 
63 Basic Facts on Productivity Change

Solomon Fabricant

1959,58 pp.. $\$ 1.00$

64 The Role of Middleman Transactions in World Trade

Robert M. Lichtenberg

1959,102 pp., $\$ 1.50$

65 Freight Transportation in the Soviet Union: A Comparison with the United States

Ernest W. Williams, Jr.

1959,47 pp., $75 €$

66 City Expenditures in the United States

Harvey E. Brazer

1959,93 pp., $\$ 1.50$

67 Trade Balances during Business Cycles: U.S. and Britain since 1880 Ilse Mintz

1959,109 pp., $\$ 1.50$

68 The Demand for Money: Some Theoretical and Empirical Results Milton Friedman

1959,25 pp., 756

69 The Average Workweek as an Economic Indicator

Gerhard Bry

1959,122 pp., $\$ 2.00$

70 Consumer Expectations, Plans and Purchases: a Progress Report

F. Thomas Juster

1959,192 pp., $\$ 2.50$

71 Changes in the Share of Wealth Held by Top Wealth-Holders, 1922-1956

Robert J. Lampman

1960,32 pp., $75 \%$

72 Housing Issues in Economic Stabilization Policy Leo Grebler

1960,140 pp., $\$ 1.50$

73 Regional Cycles of Manufacturing Employment in the United States, 1914-1953 George Borts

1960,60 pp.. $75 \zeta$

74 Changes in Labor Cost During Cycles in Production and Business Thor Hultgren

1960,102 pp., $\$ 1.50$

75 New Measures of Wage-Earner Compensation in Manufacturing, 1914-1957 Albert Rees

1960,35 pp., 756

76 American Exports During Business Cycles, 1879-1958

Ilse Mintz

1961,105 pp., $\$ 1.00$

77 Signals of Recession and Recovery: An Experiment with Monthly Reporting Julius Shiskin 1961, 203 pp., $\$ 3.00$

78 The Postwar Rise in the Velocity of Money: A Sectoral Analysis Richard T. Selden

1962, 62 pp., $\$ 1.00$

79 The American Baby Boom in Historical Perspective Richard E. Easterlin

1962,60 pp., $\$ 1.00$

80 Small-Scale Industry in the Soviet Union Adam Kaufman

1962, 111 pp., $\$ 2.00$

81 The United States Savings Bond Program in the Postwar Period George Hanc

1962, 122 pp., $\$ 1.50$

82 The Quality of Bank Loans: A Study of Bank Examination Records Albert M. Woinilower

1962, 88 pp., $\$ 1.50$ 


\section{HOW TO OBTAIN}

\section{NATIONAL BUREAU PUBLICATIONS}

National Bureau books are published and distributed by Princeton University Press; its occasional papers and technical papers are published and distributed by the National Bureau itself.

Subscribers of $\$ 75$ or more a year are entitled to receive a complimentary copy of each publication-books, occasional papers, technical papers, and the Annual Report - in advance of release to the public. In addition, the subscriber is entitled to a $331 / 3$ per cent discount on any National Bureau publication purchased.

A special subscription rate of $\$ 35$, providing the same privileges as above, is open to faculty members and students of recognized educational institutions. A limited faculty-student rate of $\$ 5$, open to faculty members and students of recognized educational institutions, entitles the subscriber to a complimentary copy of each occasional paper, technical paper, and the Annual Report, and to a 40 per cent discount on any publication purchased.

For those who wish to subscribe only to occasional papers and technical papers, the subscription rate is $\$ 4$ for five issues. A subscriber of $\$ 4$ receives the next five papers and the Annual Report.

NONSUBSCRIBERS: Order books from Princeton University Press, Princeton, New Jersey

NONSUBSCRIBERS: Order papers and request the Annual Report from:
SUBSCRIBERS: Order all books and papers and request the $A$ nnual Report from:

NATIONAL BUREAU OF ECONOMIC RESEARCH, INC. 261 Madison Avenue New York 16, N. Y.

Contributions to the National Bureau are deductible in calculating federal income taxes. 
$2,005,673$

National Bureau of Economic Research. Inc. Smith, Paul F 1910

Coit of providing consumer credit; a study of four major types of finmenal institutions. New York, National Bureau of Feonomic liesearch, 1062.

* :1 n. "-3 cin. (Natlomal Burenu of Economic Research. Occaslonal patares (3)

1. consumer credit. z. Title.

II11.12.432 no. 83

$62-21871 \ddagger$

MATERIAL SUBMITTED BY PUBLISHER. 